\title{
Oxidant - antioxidant status and some biochemical parameters in pregnant and non pregnant Iraqi she camels
}

\author{
Hayder A.N. AL-Zamely \\ Department of Physiology / College of Veteinary Medicine / University of AL-Qadisiyia
}

Accepted on 8/8/2011

\section{Summary}

This study was carried out to determine the changes in oxidant antioxidant status and some biochemical parameters in pregnant Iraqi female camels in comparison with non pregnant one. To determine this objective (30) blood samples from pregnant female camels and (30) blood samples from non pregnant female camels was taken at last state of pregnancy (number of animals are 30 in each group), blood samples were put in the test tubes contain anticoagulant (EDTA), after centrifugation serum samples were taken for measurement of Malondialdehyde (MDA), albumin, uric acid, total protein, alkaline phosphatase and urea concentrations.

The results revealed significant increase $(\mathrm{P}<0.05)$ in malon dialdehyde concentration in pregnant female camels in comparison with non pregnant. Also the results were showed insignificant decrease in albumin concentration and significant increase $(\mathrm{P}<0.05)$ in uric acid concentration in pregnant group which may be due to its antioxidant activity against lipid peroxidation during pregnancy. In related to the biochemical parameters the results were showed significant decrease $(\mathrm{P}<0.05)$ in the total protein of pregnant female camels which may be due to decrease in albumin concentration, while there is significant increase $(P<0.05)$ in ALP.

Keywords:- Camel , Pregnancy , oxidant - antioxidant , biochemical.

\section{حالة المؤكسدات - مضادات الأكسدة وبعض المعايير الكيموحيوية في النوق العراقية الحوامل مقارنة مع غير الحون الحوامل \\ فرع الفسلجة والأدوية / كلية الطب البيطري / الزاملي جامعة القادسية}

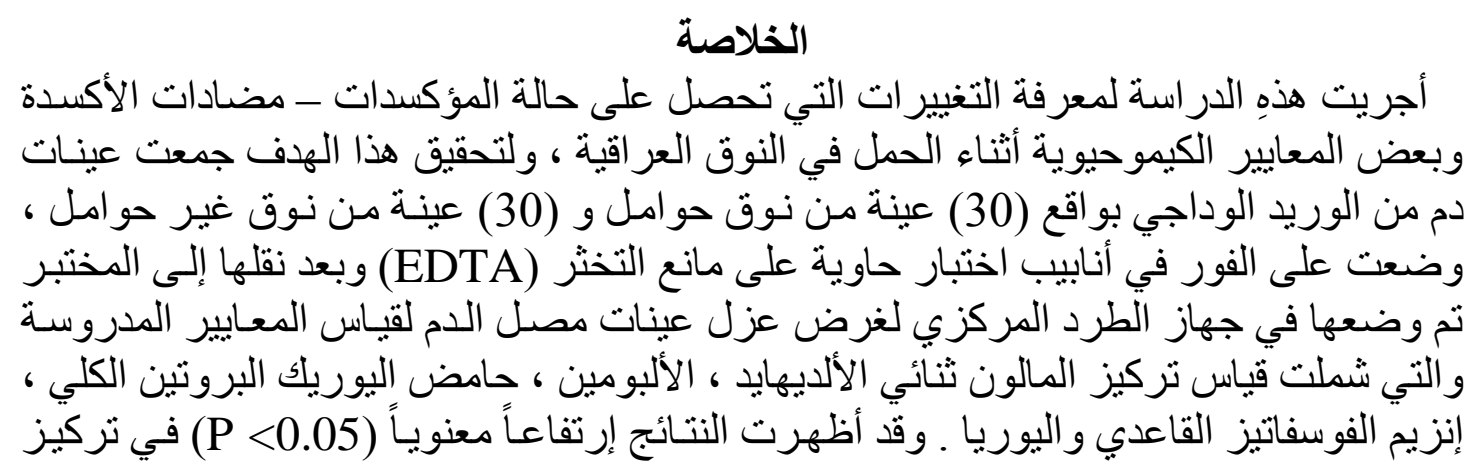


The Iraqi J. Vet. Med. 35 ( 2 ): 46 - 51; 2011

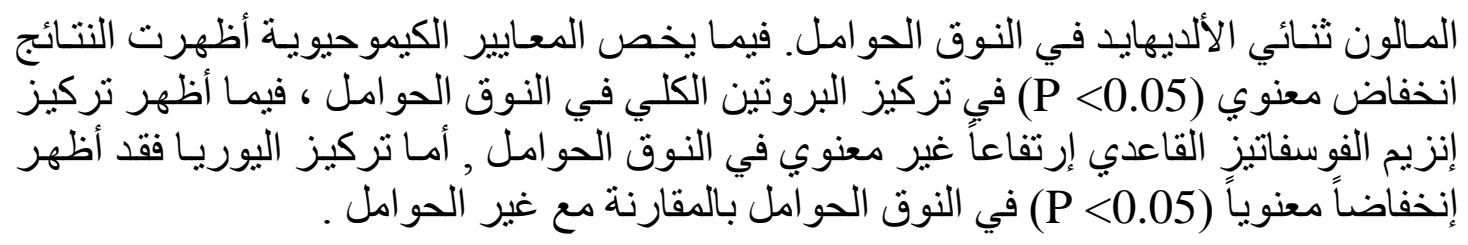

\section{Introduction}

Pregnancy ranged from 330 to 368 days in camelids. Camelids have a simple epitheliochorial placenta (1). The left and right ovaries function are equally, and it has been observed that $99 \%$ of pregnancies occur in the left uterine horn (2), because of this long pregnancy period, it was assumed that energy requirements of pregnant female camel increase rapidly during the last stage of pregnancy, and this may effect on concentrations of some biochemical parameters and oxidant - antioxidant status (3). There for this study was carried out to investigate the biochemical changes and oxidant - antioxidant status during female camel pregnancy by measuring the following parameters in the sera :malon dialdehyde (MDA), Albumin, uric acid, Total protein, Alkaline Phosphatase (ALP) and urea concentrations .

\section{Materials and Methods}

Sixty blood samples were collected from Jugular vein of pregnant and non pregnant she camels.

- Measurement of serum malondialdehyde (MDA): It is estimated by thiobarbituric acid method (4), which colouric method depend on using of thiobarbituric acid (TBA) which react with MDA to form a complex colour compound .

- Measurement of serum Albumin concentration: It was measured by Kit from Biolabo company according to (5).

- Measurement of serum uric acid concentration: Enzymetic method was used to estimate uric acid level in serum (6), and by using of kit from Spinreact company.

- Measurement of serum total protein concentration: Biuret method was used to estimate total protein level in serum (7).

- Measurement of serum Alkaline phosphatase (ALP): The colour method was used to estimate ALP activity in serum by using kit of Biomerieax company (8).

- Measurement of serum urea concentration: Serum urea level was estimated by enzymetic method (9), which depend on urease modified Biomerieux company kit.

Statistical analysis: It was done by using of statistical package for social science (SPSS) system (10). 


\section{Results and Discussion}

- Malon dialdehyde (MDA): The measurement of end products of lipid peroxidation, is the best method to estimate free radicals level in samples because free radicals have very short half life (11), therefore we estimate the effects of free radicals by estimate it's stable end products (12) . Table (1) shows the level of MDA in pregnant female camel in comparison with non pregnant, it is clear that MDA concentration is rised during pregnancy which may be due to arising of free radicals concentration during pregnancy, lipid peroxidation occure naturally in cells, therefore free radicals production also consider normal physiological process, but increased free radicals production during pregnancy may be due to that the pregnancy is stressful condition which leads to many metabolic and physiological changes including increasing of basal metabolic rate which increased clearly during pregnancy (13), and this increases in free radicals lead to increase oxidative stress due to increase lipid peroxidation (14).

- Anti oxidants (Albumin and uric acid ): Table (2) showed the effects of pregnancy on albumin and uric acid concentration, where there is show insignificant decreases $(P>0.05)$ in albumin concentration in pregnant female camels in comparison with non pregnant, this decrease may be due to decrease of albumin biosynthesis due to increase pregnancy hormones especially progesterone which is rise over $1 \mathrm{ng} / \mathrm{ml}$ in pregnant female camels (15), this increased may effect on liver and cause decreasing of albumin production (1), also increase of albumin elimination by kidney during pregnancy play a role in decrease of albumin level (16). In the another hand table (2) showed significant increase $(\mathrm{P}<0.05)$ in uric acid concentration in pregnant female camels in comparison with non pregnant, the increase of uric acid level during pregnancy because it is potent antioxidant which supply good protection for pregnant female camel against increasing lipid peroxidation this increase may be due to increase xanthin oxidase activity during liberation of free radicals during pregnancy (17).

- Biochemical parameters (Total protein , ALP and urea ): Table (3) shows that there is significant decrease $(\mathrm{P}<0.05)$ in total protein concentration in pregnant female camel in comparison with non pregnant , this decrease may be due to transport of amino acids and protein to the placenta (18), also non significant decrease $(\mathrm{P}>0.05)$ of albumin may be cause decrease of total protein because albamin is the main component of total protein (19). Also table (3) show the effect of pregnancy on ALP activity, the normal concentration of ALP in camel serum is range from 60 to $140 \mathrm{IU} /$ Liter . in this study there is non significant differences between pregnant and non pregnant female camels in related to concentration of ALP, although there is no significant increase in its 
The Iraqi J. Vet. Med. 35 ( 2 ): 46 - 51; 2011

level in pregnant in comparison with non pregnant female camels ; this increase may be due to increase its production from placenta during pregnancy (20). The importance of this enzyme come from its role in food absorption which aid in growth and development of fetus, in addition to liver and skeletal muscles which consider source of this enzyme (21). Table (3) also show significant decrease in urea concentration during pregnancy, urea is the final product of nitrogen metabolism (AL-Ani 22), it is could be excreted by kidney, the normal value of serum urea in camel range between 1 and $20 \mathrm{mmol} /$ Liter (23) . The decrease of urea during pregnancy may be due to increase glomerular filtration rate, which increase $30-50 \%$ during pregnancy (24), and this lead to increase excretion of urea, which consider the end product of amino acid catabolism . therefore the decrease of total protein during pregnancy lead to decrease urea concentration under effect of oxidative stress which cause decrease in protein synthesis in the liver (25). Under the effect of hepatic enzymes amino acids convert to uric acid which lead to increase uric acid and decrease urea level, the increase of uric acid consider defense mechanism against free radicals which increase during pregnancy (26).

Table (1) The effect of pregnancy on MDA concentration . (nanomol / Liter) .

\begin{tabular}{|c|c|}
\hline Pregnant & Non-pregnant \\
\hline $42.3 \pm 2.5^{*}$ & $30 \pm 1.3$ \\
\hline
\end{tabular}

The values represent mean \pm S.E, The number of animals $=30$ in each group, * significantly different $(\mathbf{P}<0.05)$.

Table (2) the effect of pregnancy on antioxidants (albumin and uric acid) concentration .

\begin{tabular}{|c|c|c|}
\hline $\begin{array}{c}\text { Uric acid } \\
(\mu \mathrm{mol} / \mathrm{dl})\end{array}$ & $\begin{array}{c}\text { Albumin } \\
(\mathrm{gm} / \mathrm{dl})\end{array}$ & Pregnant \\
\hline $26.3 \pm 2.5^{*}$ & $2.9 \pm 0.23$ & Non pregnant \\
\hline $20.5 \pm 3.1$ & $3.5 \pm 0.36$ & \\
\hline
\end{tabular}

The values represent mean \pm S.E, The number of animals $=30$ in each group, $*$ significantly different $(\mathbf{P}<\mathbf{0 . 0 5})$. 
The Iraqi J. Vet. Med. 35 ( 2 ): 46 - 51; 2011

Table (3) The effect of pregnancy on biochemical parameters (total protein , ALP and urea) .

\begin{tabular}{|c|c|c|c|}
\hline $\begin{array}{c}\text { Urea } \\
(\mathrm{m} \text { mol / Liter })\end{array}$ & $\begin{array}{c}\text { ALP } \\
(I U / \text { Liter })\end{array}$ & $\begin{array}{c}\text { Total protein } \\
(\mathrm{gm} / \mathrm{dl})\end{array}$ & \\
\hline $8.2 \pm 0.46^{*}$ & $82.4 \pm 0.56$ & $* 5.1 \pm 0.35$ & Pregnant \\
\hline $10.5 \pm 0.33$ & $80.5 \pm 0.39$ & $6.2 \pm 0.40$ & Non pregnant \\
\hline
\end{tabular}

The values represent mean \pm S.E, The number of animals $=30$ in each group, $*$ significantly different $(\mathbf{P}<\mathbf{0 . 0 5})$.

\section{References}

1- Pineda MH and Dooley MP (2003). McDonald's Veterinary Endocrinology and Reproduction . $5^{\text {th }}$ ed . A Blackwell publishing company . pp.46.

2- Arthur GH Noakes DE and Pearson H (1985). Veterinary Reproduction and Obstetrics . $5^{\text {th }}$ ed . Baillieere \& Tindall (publ.), Eastbouwre, U.K .

3- Ensminger ME oldfield JE and Heinemann WW(1990). Feeds and Nutrition $.2^{\text {nd }}$ ed . The Ensminger publishing co. California . USA. Pp . $1227-1260$.

4- Ceconi C Cargnoni A pasini E condorelli E Curello S and Ferrari R(1991). Evaluation of phospholipids peroxidation as a malon dialdehyde during myocardial ischemia and reperfusion in Jury. Am J physiol. 260 : 1057 1061 .

5- Doumas BT and Biggs HG (1972). Determination of serum albumin (standard methods of clinical chemistry). Acad press . N Y., $7: 175-188$.

6- Shultz A and Kaplan A (1984). Clinical Chemistry . The C.V. Mosby Co Stlouis Toronto Princeton, pp . $1261-1266$.

7- Tietz NW (1999). Textbook of Clinical Chemistry, $3^{\text {rd }}$ ed ., CA Burtis, ER Ashwood, WB saunders Co. pp. $482-485$.

8- Kind PRN and king EJ (1954). Estimation of plasma phosphatase by determination of hydrolysed phenol with amino- antipyrine. J clin path . 7 : $322-326$.

9- Patton CJ and Crouch SR(1977). Spectro - photometric and kinetics investigation of berthelot reaction for the determination of ammonia . Anal Chem . 49(3) : $464-469$.

10-SAS . (2007). SAS / STAT users guide for personal computers . SAS. Institute INC. cary N C.USA

11-Wickens D (1981). Oxidation (peroxidation) products in plasma in normal and abnormal pregnancy Lancet . $343: 511-514$.

12-Cederbery J (2001). Oxidative stress ant oxidative defences and outcome of gestation in experimental diabetes pregnancy. M. Sc . Sci Thesis uppsla Un Sweden .

13- Scott W (1994). Lipid peroxidation in pregnancy. Hypertension in pregnancy. $13(1): 1-32$.

14- Patil SB Kdliwadmath MV and Kodliwadmath SM (2007). Study of oxidative stress and enzymetic antioxidants in normal pregnancy. Indian clin biochem. 22(1) : $135-137$.

15-Elias E Bedark E and Yagil R (1984). Peripheral blood levels of progesterone in female camels. Gen comp Endocr. 53 : 235 - 240 
The Iraqi J. Vet. Med. 35 ( 2 ): 46 - 51; 2011

16- Halliwell B (1988). Albumin an important extra cellular antioxidant. Biochem Pharmacol . $37: 569-601$.

17- Sies H (1997). Antioxidants in disease mechanisms and therapy advance in pharmacology . San Diego . Academic press . 38 : 707 .

18- Writs Chafter ZT and Portland MD (1958). Free amino acids in human amniotic fluid, fetal and maternal serim . Am J Obstet Gynecol . 76(6) : $1219-1252$.

19-Champe PC and Harvey RA (2005). Lippincott's Illustrated Reviews . Biochemistry . $3^{\text {rd }}$ ed . Lippincott Williams and Wilking pp.1.

20- Pirani BBK MacGillivary F and Duncan RD (1972). Serum heat stable alkaline phosphatase in normal pregnancy and it's relationship to urinary estradiol and pregnanodiol excretion, placental weight and baby weight . J Obstet Gynecol Birt comm. 79:127-132.

21-Shane JM and Suzuki K (1974). Placental alkaline phosphatase : A review and revolution of its applicability in monitoring feto placental function . Obstet Bynecol Surv. 29 (2) : $97-105$.

22- AL-Ani FK (2004). Camel , Management and Diseases . $1^{\text {st }}$ ed . AL-Shraq printing press . Amman Jordan . pp. 167.

23- Faye B Saint-Maetin G Cherrier R and Ali Ruffa A (1992). The influence of high dietary protein energy and mineral intake on deficient young camel (Camelus dromedaries ) I- Changes in metabolic profiles and growth performance . Biochem. Physiol . 102 A : $409-416$.

24-Smuth A Beckett G Walker S and Rae P (1998). Lecture Notes on Clinical Biochemistry. $6^{\text {th }}$ ed. Blackwell Science, United Kingdom, Pp: $51-56$.

25- Sikka SC (2004). Role of oxidative stress and antioxidants in andrology and assisted reproductive technology . J Andro. $25: 5-18$.

26-Smith A Beckett G Walker S and Rae P (2003). Lecture Notes on Clinical Biochemistry , $6^{\text {th }}$ ed . Bkackwell Science, pp. 54-55. 